\title{
The Influence of Teams Games Tournament (TGT) toward Students' Interest in Arabic Language Learning
}

\author{
${ }^{1}$ Miftahul Fadliah Buhun, ${ }^{2}$ Agus Purwadi, ${ }^{3}$ Moh. Fery Fauzi* \\ Universitas Muhammadiyah Malang, Indonesia \\ 1fadliahbuhun@gmail.com, 2aguspurwadi@umm.ac.id \\ ${ }^{3}$ Corresponding E-mail: mohferyfauzi@umm.ac.id*
}

This study aimed to determine the effect of cooperative learning model of TGT type in the interest of learning Arabic language in VII grade students at MTs. Negeri Banggai Kepulauan, Central Sulawesi. The approach used in this study was a quantitative using a correlational research design. The data collecting technique was observation and questionnaires. Data was analyzed using the correlation product moment formula with the help of SPSS version 16 . The results of this Abstract study indicate that there was a significant influence on the cooperative learning model of TGT type in the interest learning Arabic language in MTs. Negeri Banggai Kepulauan, Central Sulawesi. It was proven by the score of $r_{\text {count }} 0,771$ while $r_{\text {table }}$ 0,404 . It meant that the score of $r_{\text {count }}$ was greater than the

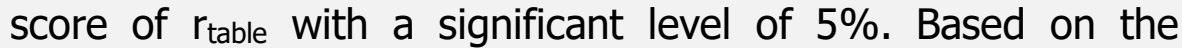
decision making criteria and testing, the cooperative learning model of TGT type in the interest learning Arabic language in VII grade students was categorized into strong category.

Keyword Cooperative Learning Model; Learning Interest; Teams Games Tournament (TGT)

$$
\begin{aligned}
& \text { تهدف هذه الدراسـة إلى تحديد أثر نموذج التعليم التعاوني بنوع بطولة } \\
& \text { الألعاب الفرقية في ميول الطلبة للصف السابع بالمدرسة المتوسطة } \\
& \text { الإسلامية الحكومية بانجي كفولاوان سولاويسي الوسطى. وكانت منهجية } \\
& \text { البحث المستخدمة لهذه الدراسة هي دراسة كمية باستخدام البحث } \\
& \text { الارتباطي. وكانت تقنية جمع البيانات بطريقة الملاحظة ونشر الاستبانة. وتم } \\
& \text { تحليل البيانات باستخدام Product Moment Pearson بمسـاعدة برنامج } \\
& \text { الإصدار } 17 \text { ـ. وكانت نتائج البحث تشير إلى وجود تأثير كبير بين نموذج }
\end{aligned}
$$

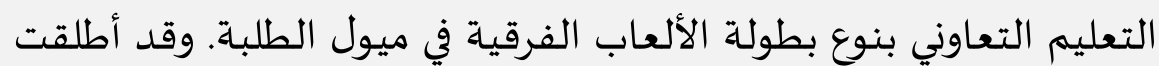
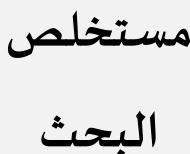

Please cite this article as Miftahul Fadliah Buhun, Agus Purwadi, Moh. Fery Fauzi. (2019). The Influence of Teams Games Tournament (TGT) toward Students' Interest in Arabic Language Learning. Izdihār : Journal of Arabic Language Teaching, Linguistics, and Literature, 2(2), 135-148. DOI: https://doi.org/10.22219/jiz.v2i2.9986 


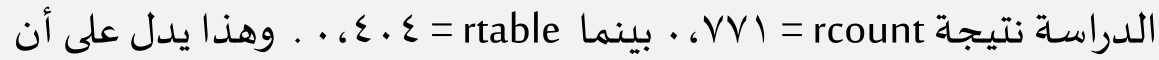

$$
\begin{aligned}
& \text { أكبر rcount من rtable . بناء على معايير صنع القرار والاختبار، تدل } \\
& \text { الدراسة على أن العلاقة بين أثر نموذج التعليم التعاوني بنوع بطولة الألعاب } \\
& \text { الفرقية في ميول الطلبة قويـة. }
\end{aligned}
$$

$$
\text { نموذج التعليم التعاوني؛ ميول في التعلم؛ بطولة الألعاب الفرقية }
$$

\section{Introduction}

Hasbullah (2012:194) said that every human being needs education, both formal and non formal education. Through education obtained, humans will grow into adults according to the educational process they experience. Through education, students are expected to be responsible for themselves and be adult.

In Islam, education is very important thing and needed for children. Parents obliged to provide proper education to children because most children will imitate what their parents do. One of the formal education is schools, each school is obliged to provide the best service and facilities to the school community in educating Indonesian citizens. School is the second place of education for students after their family environment, all school communities are responsible for the education of students.

Murdiono (2018:154) said that teaching motivation aims to encourage the students' potency within and outside themselves in carrying out all the obligations and responsibilities of learning. This can be seen from his responsibility in completing the learning assignments (PR) given by the teacher, whether students are encouraged to complete these responsibilities or not. Each teacher or student has their own problems that in accordance with the level and condition of each. One of the problem that often arises (related to teaching and learning) is a motivational problem.

A teacher has a very important task in the process of learning activities. Learning is process of interaction and activity between teachers and students, because learning achievement does not depend on what teacher convey but 
how students process the information. In learning activities, selection and use of strategies or learning models is very importaint for students' success.

One of the factors that influence students' interest in learning Arabic Language is using Arabic language learning model. Teacher must adjust with class condition. Most teachers use the lecture method because it is easier and more efficient. In fact, the lecture's method is teacher has an active role in learning activities, while students only listen to the explanation delivered by the teacher and make students bored in learning.

Mustofa (2015:127) said that learning is activity that takes place in every level of education. Success and failure of a person is very dependent on the learning process experienced by each student. So, learning is a process of changing ones behavior in a better direction.

According to Pratiwi (2015:90) an interest can be expressed through a statement that shows students prefer a thing to something else. Students who have an interest in certain subjects tend to give greater attention to the subject.

According to Astuti (2015:71) interest in learning is a feeling of pleasure, love, and concern for efforts to gain knowledge. In learning activities, students in schools learn a variety of knowledge and try so that all students get good grades, which of course can be achieved by having a high interest in learning.

Fauzi and Anindiati (2019:131) said that the mobile phones is used not only for communication but also for many benefits. It can be used for entertainment, facebook, music, and others. Through mobile phones, students can add knowledge about lesson that has not understand and increase students' interest in learning.

Interest is very influential factor in the learning process, because interest is a desire that occurs from within a person to do the things he wants. A teacher must try to make students interested in learning more, because through students' interest, the teacher can be very helpfull. Then, teachers pay more attention to teach materials used in the learning process and teacher attitudes towards students. 
According to Hanafy (2014:66) learning is defined as the process of changing behavior as a result of individual interaction with their environment. The changing of behavior is continuous, functional, positive, and directed.

Dumont, Istance, and Benavides (2010:14) said that the learning environment recognizes the learners as its core participants, encourages their active engagement and develops in them an understanding of their own activity as learners.

Tayeb (2017:48) said that learning models are interpreted as conceptual frameworks that describe systematic procedures in organizing learning experiences to achieve certain learning goals, and serve as guidelines for learning designers and instructors in planning and implementing learning activities.

According to Imam Makruf (2009:99-100) learning Arabic language is a process of teaching and learning activities carried out by Arabic teachers in delivering knowledge to students. The process of teaching and learning activities is a condition created by the teacher so that students can learn well. Through foreign languages, students can communicate and understand in groups of learning (Hasyim Asy'ari dan Ammar Zainuddin, 2018 : 174).

Somethings that happen at MTs. Negeri Banggai kepulauan especially class VII is the process of teaching and learning activities only carried out by the lecture method, this makes students passive. Through these problems, researcher extracted for seeing the effect for using the cooperative learning model of Teams Games Tournament (TGT) type in the learning process to increase students learning interest in Arabic subjects.

According to Robyn M. Gillies (2016:39) Cooperative learning is widely recognized as a pedagogical practice that promotes socialization learning among students and across different subject domains. Cooperative learning involves students working together to achieve common goals.

Cooperative learning model of Teams Games Tournament (TGT) type is one of the cooperative models in which students in groups of 4 to 6 students, in each group, there are students who have various abilities. Learning with Teams Games Tournament (TGT) model will require students to interact with each other, such as between teachers and students as well as between students and 
students in their groups so that they can help students understand the lesson provided (Mudrika, 2018:77).

Through cooperative learning model of Teams Games Tournament (TGT) type can provide opportunities for students to interact openly with their groups and their teaching and learning process by holding small tournaments. Teams Games Tournament (TGT) learning model consists of five steps: class presentation, group learning, games, tournament, and group awards (Rizmahardian Ashari Kurniawan, 2017 : 42)

According to Maulana Ibnu Soleh (2017:2104) the application of the cooperative learning model of Teams Games Tournament (TGT) type that realizes students play an active role and can learn more calmly besides being able to create a sense of responsibility, cooperation, competition between teams in a healthy manner, and learning involvement, so that it is expected to change students learning interest in a better direction. Based on the explanation above, it is expected that through this cooperative learning model of Teams Games Tournament (TGT) type can increase students interest in Arabic subjects.

\section{Method}

\section{Identify Subsections}

The approach used in this study is a quantitative. The research design used in this study is a correlation research design. Correlation research is research that intended to determine whether there is a relation between two or several variables in a study of a subject group.

\section{Participant (Subject) Characteristics}

According to Nanang Martono (2014:76), the population can be defined as whole individual in the scope to be studied. So, the population is the whole object or subject within the scope of the research. The population in this research all VII grade students at MTs. Negeri Banggai Kepulauan. While the sample is member of population selected using certain procedures so that they are expected to represent the population. The sample from this research is 
class VIIA and class VIIB. The sampling technique is taken by Proportionate Stratified Random Sampling that is carried out the members in the population are heterogeneous and proportionately structured.

The object of research is the object that used as research or the focus of research. This research is about the influence of cooperative learning model of Teams Games Tournament (TGT) type to interest study Arabic language in MTs. Negeri Banggai Kepulauan. The object of this research is VII grade students at MTs. Negeri Banggai Kepulauan.

\section{Research Design}

Data collection techniques used firstly in this research is observations. Observation is a process of direct observation of the object research. The Second is spreading questionnaire. According to Isti Pujihastuti (2010 : 44) questionnaire is a primary data collection tool with a survey method to obtain respondents opinions. Questionnaires can be used to obtain personal information such as respondents attitudes, expectations and desires.

The steps taken the data collection procedure, the first stage: determine the location and time of research, arrange research permits, conduct field observations before conducting research, determine the lesson to be taught during research, and compile research instruments as teaching designs with cooperative learning model of Teams Games Tournament (TGT) type. Implementation stage: researchers used two classes, class VIIA and class VIIB. The stages in implementing cooperative learning model of Teams Games Tournament (TGT) type as follows: class presentations, group division, games, tournament, and team awards. Evaluation stage: distributing questionnaires to VII grade students, to find out the interest of learning Arabic language at MTs. Negeri Banggai Kepulauan.

\section{Result and Discussion}

\section{A. Research Result}

\section{Questionnaire Result}

\section{a. Test Validity Questionnaire}

After the question was tested, then the researcher counted using the SPSS version 16. Decision making on the validity test is carried out with a significant level $(a)=5 \%$ and the border of $r_{\text {table }}$ with the amount $(n) 50$ obtained by $r_{\text {table }}$ of 0,279 in table $r$. Question is said to be valid if $r_{\text {count }}>$ 
0,279 . The output of the question validity using SPSS 16 is complete can be seen in table 1.

Table 1. The Results of The Validity Test Questionnaire

\begin{tabular}{|c|c|c|c|c|c|}
\hline No. & $\begin{array}{c}\text { Pearson } \\
\text { Correlations } \\
\left(\mathbf{r}_{11}\right)\end{array}$ & Decision & No. & $\begin{array}{c}\text { Pearson } \\
\text { Correlations } \\
\left(\mathbf{r}_{11}\right)\end{array}$ & Decision \\
\hline 1 & 0,595 & Valid & 18 & 0,194 & Invalid \\
\hline 2 & 0,087 & Invalid & 19 & 0,198 & Invalid \\
\hline 3 & 0,073 & Invalid & 20 & 0,048 & Invalid \\
\hline 4 & 0,410 & Valid & 21 & 0,632 & Valid \\
\hline 5 & 0,115 & Invalid & 22 & 0,583 & Valid \\
\hline 6 & 0,438 & Valid & 23 & 0,128 & Invalid \\
\hline 7 & 0,544 & Valid & 24 & 0,536 & Valid \\
\hline 8 & 0,099 & Invalid & 25 & 0,515 & Valid \\
\hline 9 & 0,655 & Valid & 26 & 0,427 & Valid \\
\hline 10 & 0,534 & Valid & 27 & 0,486 & Valid \\
\hline 11 & 0,577 & Valid & 28 & 0,376 & Valid \\
\hline 12 & 0,573 & Valid & 29 & 0,606 & Valid \\
\hline 13 & 0,441 & Valid & 30 & 0,104 & Invalid \\
\hline 14 & 0,587 & Valid & 31 & 0,123 & Invalid \\
\hline 15 & 0,176 & Invalid & 32 & 0,257 & Tidak Valid \\
\hline 16 & 0,314 & Valid & 33 & 0,173 & Invalid \\
\hline 17 & 0,475 & Valid & & & \\
\hline
\end{tabular}

From the table 1 of data using SPSS 16, there were 20 valid questionnaires and 13 invalid questionnaires. The valid questionnaires of were number $1,4,6,7,9,10,11,12,13,14,16,17,21,22,24,25,26,27$, 28 , and 29. 


\section{b. Reliability Test Questionnaire}

After the validity test, the instrument reliability test will be carried out. This reliability test is not done on all questions, but only on the question of declared valid. The data is processed to find out the reliability coefficients using the Alpha Cronbach formula whose results described in the form as below:

$$
\begin{aligned}
& \mathrm{O}^{1}=510-\frac{112^{\mathrm{x}}}{25}=\frac{8,24}{25}=0,33 \quad \mathrm{O}^{11}=562-\frac{118^{\mathrm{x}}}{25}=\frac{5,04}{25}=0,21 \\
& \mathrm{O}^{2}=553-\frac{117^{\mathrm{x}}}{25}=\frac{5,44}{25}=0,22 \quad \mathrm{O}^{12}=519-\frac{113^{\mathrm{x}}}{25}=\frac{8,24}{25}=0,33 \\
& \mathrm{O}^{3}=553-\frac{117^{\mathrm{x}}}{25}=\frac{5,44}{25}=0,22 \quad \mathrm{O}^{13}=571-\frac{119^{\mathrm{n}}}{25}=\frac{4,56}{25}=0,19 \\
& \mathrm{O}^{4}=510-\frac{112^{\mathrm{x}}}{25}=\frac{8,24}{25}=0,33 \quad \mathrm{O}^{14}=571-\frac{119^{\mathrm{x}}}{25}=\frac{4,56}{25}=0,19 \\
& \mathrm{O}^{5}=546-\frac{116^{\mathrm{x}}}{25}=\frac{7,76}{25}=0,32 \quad \mathrm{O}^{15}=598-\frac{122^{\mathrm{x}}}{25}=\frac{2,64}{25}=0,11 \\
& \mathrm{O}^{6}=553-\frac{117^{\mathrm{x}}}{25}=\frac{5,44}{25}=0,22 \quad \mathrm{O}^{16}=580-\frac{120^{\mathrm{x}}}{25}=\frac{4}{25}=0,16 \\
& \mathrm{O}^{7}=553-\frac{117^{2}}{25}=\frac{5,44}{25}=0,22 \quad \mathrm{O}^{17}=580-\frac{120^{\mathrm{x}}}{25}=\frac{4}{25}=0,16 \\
& \mathrm{O}^{8}=571-\frac{119^{\mathrm{x}}}{25}=\frac{4,56}{25}=0,19 \quad \mathrm{O}^{18}=580-\frac{120^{\mathrm{x}}}{25}=\frac{4}{25}=0,16 \\
& \mathrm{O}^{9}=562-\frac{118^{\mathrm{2}}}{25}=\frac{5,04}{25}=0,21 \quad \mathrm{O}^{19}=571-\frac{119^{\mathrm{2}}}{25}=\frac{4,56}{25}=0,19 \\
& \mathrm{O}^{10}=562-\frac{118^{\mathrm{x}}}{25}=\frac{5,04}{25}=0,21 \quad \mathrm{O}^{20}=580-\frac{120^{\mathrm{s}}}{25}=\frac{4}{25}=0,16
\end{aligned}
$$

$s_{i}^{2}=0,33+0,22+0,22+0,33+0,32+0,22+0,22+0,19+0,21+0,21$ $+0,21+0,33+0,19+0,19+0,11+0,16+0,16+0,16+0,19+0,16=$ 4,33

Then, the total variance score:

$s_{t}^{2}=220735-\frac{2347^{2}}{25}=\frac{398,64}{25}=15,95$

Then, Input to Alpha formula:

$$
\begin{aligned}
& \mathrm{r}_{11}=\left[\frac{n}{n-1}\right]\left[1-\frac{s_{i}^{2}}{s_{t}^{2}}\right] \\
& \mathrm{r}_{11}=\left[\frac{20}{20-1}\right]\left[1-\frac{4,33}{15,95}\right]=[1,052][0,72]=0,75
\end{aligned}
$$

Interpretation of $r_{11}$ score is:

$0,90<r_{11} \leq 1,00$ : very high reliability

$0,70<r_{11} \leq 0,90$ : high reliability

$0,40<\mathrm{r}_{11} \leq 0,70$ : moderate reliability

$0,20<r_{11} \leq 0,40$ : low reliability 
$r_{11} \leq 0,20 \quad$ : very low reliability

Based on the results of manual account, reliability score is 0,75 which interpreted the research instruments included in the category have high reliability.

\section{Data Analysis}

Data analysis is a step that is used to answer the problem statement in the research with the purpose of obtaining conclusions from the results of research. Data analysis technique used in this study was product moment correlation formula. Through this hypothesis test we can find out whether the formulated hypothesis can be accepted or rejected. The hypothesis that will be tested is:

$\mathrm{H}_{\mathrm{o}}=$ There is no effect of the cooperative learning model of Teams Games Tournament (TGT) type to interest in learning Arabic Language in MTs. Negeri Banggai Kepulauan.

$\mathrm{H}_{\mathrm{a}}=$ There is the influence of the cooperative learning model of Teams Games Tournament (TGT) type to interest in learning Arabic Language in MTs. Negeri Banggai Kepulauan.

Table 2. The Results of The Questionnaire From Team Games Tournament to Interest Learning Arabic at MTs. Negeri Banggai

Kepulauan

\begin{tabular}{ccc}
\hline No & Item & Score \\
\hline 1. & Cooperative Learning Model of & $\sum X_{1}=1156$ \\
& TGT Type $\left(\mathrm{X}_{1}\right)$ & \\
2. & Interest To Learn $\left(\mathrm{X}_{2}\right)$ & $\sum X_{2}=1175$ \\
3. & $\boldsymbol{X}_{1}^{2}$ & $\sum X_{1}^{2}=53646$ \\
4. & $\boldsymbol{X}_{2}^{2}$ & $\sum X_{2}^{2}=55357$ \\
5. & $\boldsymbol{X}_{1 X_{2}}$ & $\sum X_{1 X_{2}}=54455$ \\
\hline
\end{tabular}

Table 2 explained about score of questionnaires given to students of MTs. Negeri Banggai Kepulauan. The score from questionnaires were used to count product moment pearson correlation coefficient, the following formula is used:

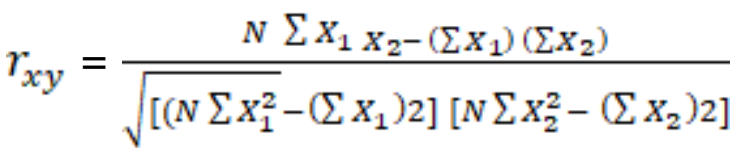


$r=\frac{25(54455)-(1156)(1175)}{\sqrt{\left[\left(25(53646)-(1156)^{2}\right]\left[25(55357)-(1175)^{2}\right]\right.}}$

$r=\frac{3075}{\sqrt{(4814 \times 3300)}}$

$r=\mathbf{0 , 7 7 1 4 9 8 5}$ rounded to $\mathbf{0 , 7 7 1 5}$

To test the results of product moment correlation coefficient, researchers connected it to the product moment correlation table $\left(r_{\text {table }}\right)$, but beforehand the degree of freedom (df) must be sought. Formula looking for $\mathrm{db}=\mathrm{N}-1$; because $\mathrm{N}=25$, then $\mathrm{db}=25-1=24$.

On rable with significant $5 \%$ and $1 \%$ of $d b=24$ each is 0,404 and 0,515 , then

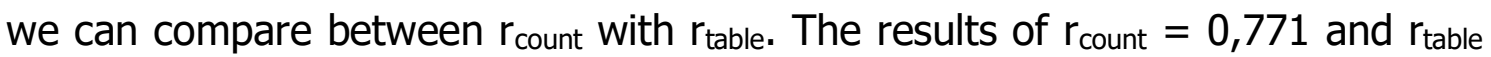
$0,515(1 \%)$ and $0,404(5 \%)$. It can be seen that, both with a significant level a $=0,05$ and $a=0,01$; the price of $r_{\text {count }}$ was bigger $(>)$ than $r_{\text {table }}$.

The following table was results of SPSS program for product moment correlation:

Table 3. Correlation between two research variables

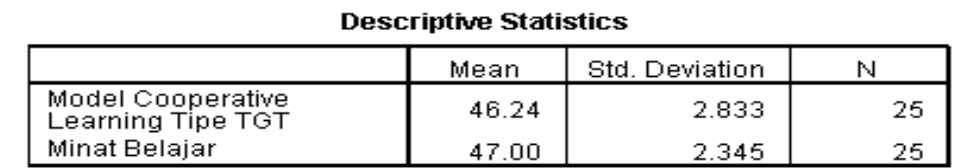

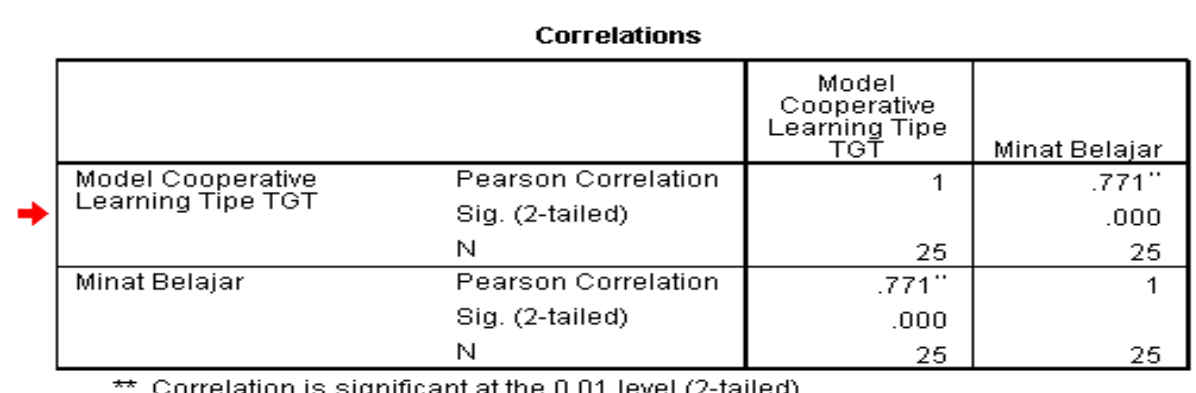

Correlation is significant at the 0.01 level (2-tailed)

In the table 3 , it can be seen that the score of $r_{\text {count }}$ was bigger $(>)$ than $r_{\text {table }}$ which its result was $0,771>0,404$. It means that $H_{0}$ is rejected and $H_{a}$ is accepted. So it can be concluded that the cooperative learning model of Team Games Tournament influences the interest students' of MTs. Negeri Banggai Kepulauan in learning Arabic Language.

To give an interpretation of size the correlation coefficient, it can be guided by the standard provisions listed in the following table: 
Table 4. Interpretation of The Correlation Coefficient

\begin{tabular}{cc}
\hline Coefficient Interval & Degree Of Correlation \\
\hline $\mathbf{0 , 0 0 - 0 , 1 9 9}$ & Very Low \\
$\mathbf{0 , 2 0}-\mathbf{0 , 3 9 9}$ & Low \\
$\mathbf{0 , 4 0}-\mathbf{0 , 5 9 9}$ & Medium \\
$\mathbf{0 , 6 0 - 0 , 7 9 9}$ & Strong \\
$\mathbf{0 , 8 0 - 1 , 0 0}$ & Very Strong \\
\hline
\end{tabular}

The result of correlation between two variables in the research was 0,771 . It can be interpreted by using coefficient interval in table 4 as a strong correlation. The result of the influence of Teams Games Tournament (TGT) toward Students' Interest in Arabic Language Learning is strong.

This study can be generalized for other subjects in school or other learnings. Cooperative learning model of Teams Games Tournament (TGT) type provide opportunities for students to interact and socialize openly with groups in teaching and learning process through small tournaments.

Teams Games Tournament (TGT) is widely recognized as a pedagogical practice that promotes socialization learning among students and across different subject domains. It involves students working together to achieve common goals.

Figure 1. Cone of Experience by Edgar Dale

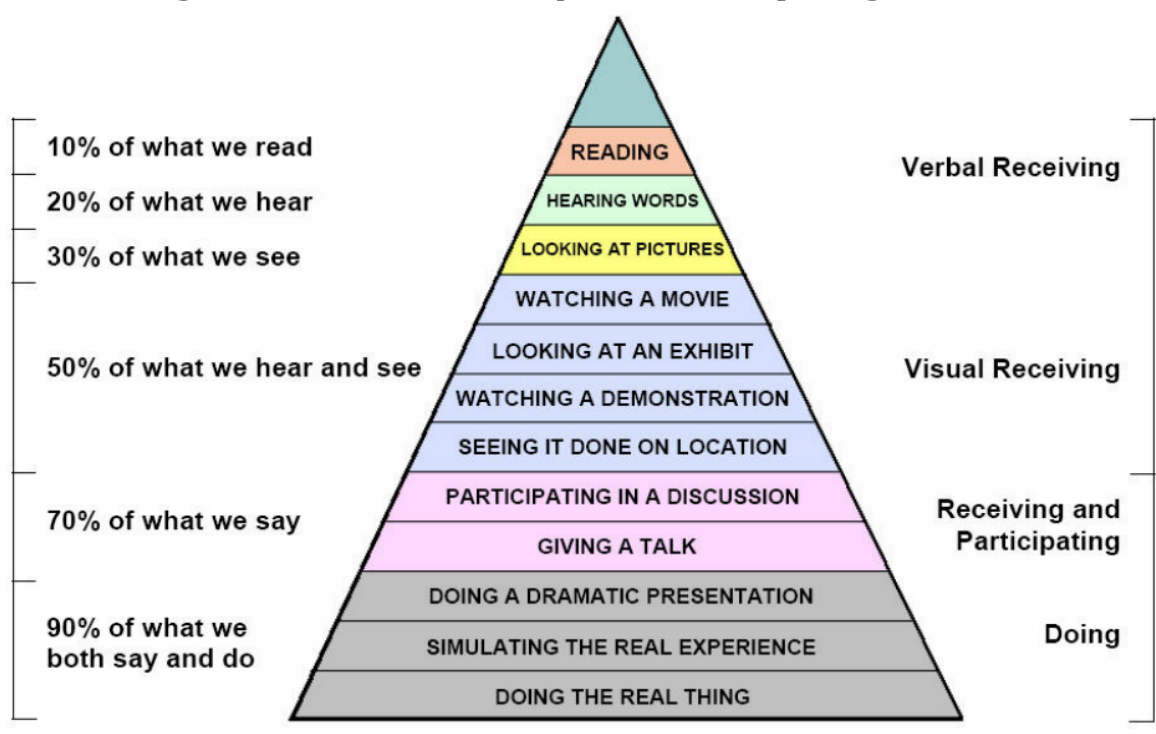

Figure 1 explains about the cone of experience by Edgar Dale. Teams Games Tournament (TGT) strategy can increase students' understanding in learning because students participate in discussion, giving talk, interacting and 
socializing in teams. It can be indicated from the results of research that result the influence of Teams Games Tournament (TGT) toward Students' Interest in Arabic Language Learning is strong.

The cone of experience was stated firstly by Edgar Dale. It is admirable and powerful idea to be used for learning. But, the important thing to be discussed is about educational strategies, educational research, and pedagogy in general. In this case, the cone's descending levels represented increasingly involved learning experiences that Dale envisioned would place watching an educational films into a larger context of concrete learning experiences (Jackson, 2016:52).

\section{Conclusion}

Based on the results of the research in the discussion above, it can be concluded there is the influence cooperative learning model of TGT towards students interest in learning Arabic Language at MTs. Negeri Banggai Kepulauan which is indicated by the score of $r_{\text {count }}=0,771$ while $r_{\text {table }}=0,404$. Then the score of $r_{\text {count }}$ is greater than the score of $r_{\text {table }}$ with a significant level of $5 \%$, thus the hypothesis states $\mathrm{H}_{a}$ is accepted and $\mathrm{H}_{\mathrm{O}}$ is rejected. Meaning that the cooperative learning model of TGT has an influence on the interest in learning Arabic Language at VII grade students MTs. Negeri Banggai Kepulauan. Based on the decision making criteria and testing, the coopertive learning model of TGT in the interest learning Arabic Language is included in the strong category.

\section{Bibiliography}

Astuti, S. P. (2015). Pengaruh Kemampuan Awal dan Minat Belajar. Jurnal Formatif, 5

68-75. https://doi.org/http://dx.doi.org/10.30998/formatif.v5i1.167

Bisri, M. (2015). Psikologi Pendidikan. Yogyakarta: Parama Ilmu.

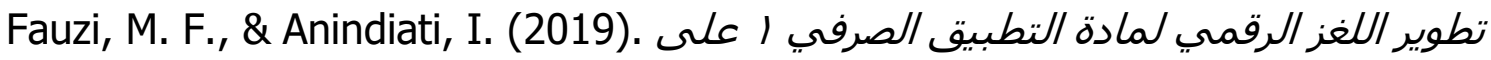

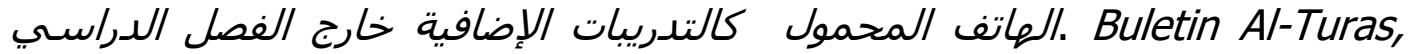
XXV (1), 129-140.

Gillies, R. M. (2016). Cooperative learning: Review of Research and Practice. Australian Journal of Teacher Education, 41 (3), 39-54. https://doi.org/10.14221/ajte.2016v41n3.3 
Groff, J. (2012). The Nature of Learning: Using Research to Inspire Practice for the Practitioner Guide. 1-12. Retrieved from http://www.oecd.org/edu/ceri/50300814.pdf

Hanafy, Muh. Sain. (2014). Konsep Belajar dan Pembelajaran. Lentera Pendidikan, 17 (1), 66-79. http://103.55.216.55/index.php/lentera_pendidikan/article/viewFile/516/49 1

Hasbullah. (2012). Dasar -Dasar Ilmu Pendidikan. Jakarta: Raja Grafindo Persada.

Ibnu, M., \& Kurnia, D. (2017). Penerapan Model Pembelajaran Kooperatif Tipe Teams Games ( TGT) Pada PIPS District. Jurnal Pena IImiah, 2 (1), 21012110.

Imam, M. (2009). Strategi Pembelajaran Bahasa Arab Aktif. Semarang: Need's Press.

Jackson, J. (2016). Myths of Active Learning: Edgar Dale and the Cone of Experience. Journal of the Human Anatomy and Physiology Society, 20(2), 51-53.

Kurniati, T., \& Kurniawan, R. A. (2018). Pengaruh Pembelajaran Kooperatif Tipe Tgt Dan Gaya Belajar Model Vark Terhadap Hasil Belajar Kimia Sekolah Pada Mahasiswa Program Studi Pendidikan Kimia. Jurnal Pendidikan $\begin{array}{llllll}\text { Matematika Dan } & 8 & \text { (2), }\end{array}$ https://doi.org/10.26418/jpmipa.v8i2.21174

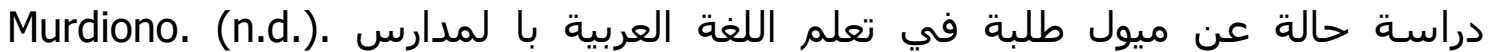
المتوسطة الإسلامية بمالانج و باتو. Jurnal Izdihar, 177-10r , r, 1

Mudrika, \& Wijaya, M. (2018). Penerapan Model Pembelajaran Kooperatif Tipe TGT Untuk Meningkatkan Motivasi dan Aktivitas Belajar Peserta Didik Kelas X MIA-3 SMAN 1 Tanete Rilau (Studi pada Materi Pokok Ikatan Kimia dan Bentuk Geometri). Jurnal Chemica, 19 (6), 75-86.

Nanang, M. (2014). Metode Penelitian Kuantitatif: Analisis Isi dan Analisis Data Sekunder. Jakarta: Rajawali Press.

Pratiwi, N. K. (2015). Pengaruh Tingkat Pendidikan, Perhatian Orang Tua, Dan Minat Belajar Siswa Terhadap Prestasi Belajar Bahasa Indonesia Siswa Smk Kesehatan Di Kota Tangerang. Jurnal Pujangga, 1 (2), 75-105.

Pujihastuti, I. (2010). Isti Pujihastuti Abstract. Jurnal Agribisnis Dan Pengembangan Wilayah, 2(1), 43-56.

Slameto. (2010). Belajar dan Faktor - Faktor yang Mempengaruhinya. Jakarta: PT. Rineka Cipta. 
Tayeb, T. (2017). Analysis and Benefits of Learning Models. Jurnal Pendidikan Dasar Islam, 4 (2), 48-55. Retrieved from https://doi.org/10.24252/auladuna.v4i2a5.2017 Analisis

Zainuddin, A. (n.d.). تعليم اللغة العربية في المعهد السلفي و المعهد الحديث نماذبا . Jurnal Izdihar, $1 \wedge \cdot-17 V$. $\Gamma, 1$ 